\title{
COMPARISON OF FEATURES OF THE EPIDERMIS AND THE SIZE OF THE FLORAL NECTARY IN FOUR SPECIES OF THE GENUS Cotoneaster Med.
}

\author{
Mirosława Chwil, Elżbieta Weryszko-Chmielewska
}

\author{
Department of Botany, University of Life Sciences in Lublin, Akademicka 15, 20-950 Lublin, Poland, \\ e-mail: miroslawa.chwil@up.lublin.pl
}

Received: 03.09.2011

\begin{abstract}
The investigations involved four species of the Cotoneaster genus: C. divaricatus, C. horizontalis, C. lucidus, $C$. praecox, which are commonly grown for decorative purposes. In Poland, these plants bloom in May and June and are a source of abundant spring nectar flow for insects. The floral nectaries of the above-mentioned species were examined using stereoscopic, light, and scanning electron microscopy in order to assess their size and epidermal microstructure. In the plants studied, the upper part of the hypanthium is lined by nectariferous tissue. The nectaries in the four species vary in terms of their sizes. Nectar is secreted onto the surface of the epidermis through anomocytic, slightly elongated or circular stomata. The largest stomata on the nectary epidermis were found in the flowers of $C$. horizontalis, and the smallest ones in $C$. divaricatus. Their size and location in relation to other epidermal cells were taxon-specific. The highest density of stomata in the nectary epidermis was found in $C$. divaricatus $\left(205\right.$ per $\mathrm{mm}^{2}$ ), whereas $C$. horizontalis flowers exhibited the lowest $\left(98\right.$ per $\mathrm{mm}^{2}$ ) stomatal density. The cuticular ornamentation on the nectary epidermis surface was diverse. The stomatal indices calculated for the nectary epidermis were considerably lower than for the leaves in the particular species.
\end{abstract}

Key words: Cotoneaster, four species, nectaries, micromorphology, epidermis, stomatal index

\section{INTRODUCTION}

The genus Cotoneaster (Rosaceae) comprises 60 species occurring in Europe, Asia and north-west Africa. Various plant habits - from creeping shrubs to small trees - are found within the genus. The plants produce small, white or pink inflorescences that can be single or form small cymes or corymbs ( $\mathrm{S} \mathrm{z} \mathrm{w} \mathrm{e} \mathrm{y} \mathrm{-}$ k ow s c y, 2003).

The four species of the genus Cotoneaster investigated in this study are commonly planted for decorative purposes in Poland. C. divaricatus Rehder at E. H. Wilson, C. horizontalis Decne and C. praecox M. Vilm ex Bois at Berthault originate from China. On their short shoots, they produce single or clustered (2-3) flowers with a pink or white corolla. Owing to its shoot habit, $C$. horizontalis is often grown in rock gardens. C. lucidus Schltdl originates from Siberia and is resistant to frost. Its flowers characterised by white-pink corolla petals form clusters of 3-8 (15). In the Polish conditions, the species in question bloom in May and June (Szweykowscy, 2003; Seneta and Dolat ow ski, 2004).

The flowers of the above-mentioned taxa are a rich source of nectar flow for insects. Current research indicates that the flowers of various species of the genus Cotoneaster vary markedly in nectar yield (2-13 mg/flower) and sugar yield (0.9-2.9 mg/flower), which is a measure of their attractiveness to pollinators (Szklanowska, 1978; Jabłoński and Koltowski, 1996; Weryszko-Chmielewska and Konarska, 1996, Weryszko-Chmielew s k a et al. 2003, 2004), especially honeybees and bumblebees (Corbet and Westgarth-S mith, 1992). These authors have found that phenological studies allow selecting those Cotoneaster taxa for plantings that provide the most valuable nectar flow for honeybees.

Relatively easily accessible nectar in Cotoneaster flowers is secreted by the nectaries that are recessed in the flower. Fahn (1979), Radice and Galati (2003) as well as Weryszko-Chmielewska et al. (2003) have found receptacular nectaries in Rosaceae, whereas S m e ts (1986), Ev a n s and Dickinson (2005) and Bernardello (2007) have reported that the nectariferous tissue in this family is located on the inner surface of the hypanthium. The nectariferous tissue in the species studied is 
composed of 2-17 layers of different-sized glandular cells (Weryszko-Chmielewska and Konarska, 1996).

This research was a continuation of an earlier study on the nectary structure in representatives of the family Rosaceae. The present study compared the micromorphology of the epidermis of the floral nectaries in four species belonging to the genus Cotoneaster. Stomatal density per unit area of epidermis and stomatal indices were calculated. The size of the nectaries was compared. A comparison was made of the stomatal indices for the nectary epidermis and leaves of the same plant species.

\section{MATERIALS AND METHODS}

Flowers of four species of the genus Cotoneaster were selected for the study: $C$. divaricatus Herder at E. H. Wilson, C. horizontalis Decne, C. lucidus Schltdl, and $C$. praecox M. Vil ex Bois at Berthault; the nomenclature follows Mirek et al. (2002). According to other authors, $C$. horizontalis is synonymous with C. hjelmqvistii Flinik at Hylmö (Rutkowski, 2004).

The nectary sizes $(n=6)$ and the epidermal microstructure were examined with the use of stereoscopic, light, and scanning electron microscopy. A stereoscopic microscope was used for preliminary observations and measurements of the nectaries. The stomatal index was calculated in accordance with the method developed by B roda (2002). For a more comprehensive evaluation of stomatal sizes and density on the nectary epidermis, the lengths and widths of leaf stomata as well as respective stomatal indices were compared. The shape index was calculated based on the stomatal length and width.
The surface of the nectary epidermis was observed under a scanning electron microscope (SEM), for which flower fragments were fixed in $4 \%$ glutaraldehyde, in $0.1 \mathrm{M}$ phosphate buffer ( $\mathrm{pH}$ 7.2). The sections were dehydrated in alcohol and acetone series. Next, they were critical-point dried in liquid $\mathrm{CO}_{2}$. The sections were coated with gold using a CS 100 Sputter Coater and observed under a LEO 1430VP scanning electron microscope.

The number of stomata per unit area was calculated and the measurements of epidermal cells were performed with the use of NIS - Elements AR version 3.10 imaging software.

\section{RESULTS}

In the flowers of the taxa studied, the nectariferous tissue is located in the upper part of the hypanthium between the base of the styles and the base of the staminal filaments (Figs 1B-D, F; 2A, B; 3A; 4A, B; $5 \mathrm{~A})$. The nectary of the Cotoneaster species investigated is yellow or green-yellow, and it clearly contrasts with the massive red filaments (Fig. 1B-D, F) arranged in two whorls. The number of stamens in the flowers ranges between 13 and 20. Numerous glistening non-glandular trichomes (Figs 1B-D, F; 2A, C; 3A; 4A, B; $5 \mathrm{~A})$ are present at the base of the styles (2-3). The upper parts of the coloured stamens, bent towards the flower centre, provide protection for the nectary and, simultaneously, play the role of an attractant (Fig. 1A-F).

The nectaries of the four species analysed differ in size. The biggest nectariferous glands with the largest diameter and greatest height were found in $C$. lucidus; in turn, the glands in $C$. divaricatus were the smallest. In the other two taxa, the nectaries were similar in size (Table 1).

Table 1

Characteristics of the nectary in the flowers of the four species of the genus Cotoneaster

\begin{tabular}{lcc}
\hline \multirow{2}{*}{\multicolumn{1}{c}{ Species }} & Height & Diameter \\
\cline { 2 - 3 } & \multicolumn{2}{c}{ of the nectary } \\
\cline { 2 - 3 } & \multicolumn{2}{c}{$(\mathrm{mm})$} \\
\hline C. divaricatus & $1.2 \pm 0.10$ & $1.7 \pm 0.19$ \\
C. horizontalis & $1.2 \pm 0.12$ & $2.2 \pm 0.17$ \\
C. lucidus & $1.9 \pm 0.15$ & $2.3 \pm 0.16$ \\
C. praecox & $1.3 \pm 0.24$ & $2.3 \pm 0.11$ \\
\hline
\end{tabular}

In representatives of the genus Cotoneaster, nectar is released onto the surface of the nectary epidermis through the stomata, which differed in shape: they were either slightly elongated or circular in the particular taxa. The other epidermal cells of the nectary were polygonal and had slightly convex and undulate outer walls (Figs 2C-D; 3B-E; 4C-E; 5B-D). 
Table 2

Characteristics of the nectary epidermis in the flowers of the four species of the genus Cotoneaster

\begin{tabular}{|c|c|c|c|c|}
\hline \multirow{2}{*}{ Feature examined } & \multicolumn{4}{|c|}{ Cotoneaster } \\
\hline & divaricatus & horizontalis & lucidus & praecox \\
\hline \multicolumn{5}{|c|}{ Stomata } \\
\hline Stomatal opening during nectar secretion & open or closed & open & open or closed & open \\
\hline $\begin{array}{l}\text { Position of stomata in relation to other } \\
\text { epidermal cells }\end{array}$ & at the same level & light depressions & at the same level & in slight depressions \\
\hline \multicolumn{5}{|c|}{ Other epidermal cells } \\
\hline \multirow{2}{*}{$\begin{array}{ll}\text { Number of } & \begin{array}{l}\text { around the stomata } \\
\text { cells }\end{array} \\
& \begin{array}{l}\text { in the epidermis between } \\
\text { adjacent cells }\end{array} \\
\end{array}$} & $5-7$ & $8-9$ & 6 & $6-7$ \\
\hline & $2-8$ & $4-13$ & $4-15$ & $3-9$ \\
\hline Presence of wax & + & + & + & + \\
\hline Structure of cuticular wax & \multicolumn{4}{|c|}{ granular or composed of larger irregular forms } \\
\hline
\end{tabular}

Table 3

Characteristics of nectary epidermis in the four species of the genus Cotoneaster

\begin{tabular}{|c|c|c|c|c|c|c|}
\hline \multirow{3}{*}{ Species } & Length & Width & \multirow{3}{*}{ Shape index } & \multicolumn{2}{|c|}{ Number } & \multirow{2}{*}{ Stomatal index } \\
\hline & \multicolumn{2}{|c|}{ of stomata } & & of stomata & of epidermal cells & \\
\hline & \multicolumn{2}{|c|}{$(\mu \mathrm{m})$} & & \multicolumn{2}{|c|}{$\left(\right.$ per $\left.1 \mathrm{~mm}^{2}\right)$} & $(\%)$ \\
\hline C. divaricatus & 18.3 & 11.5 & 1.6 & 205 & 4339 & 4.5 \\
\hline C. horizontalis & 22.5 & 17.9 & 1.3 & 98 & 10952 & 0.9 \\
\hline C. lucidus & 18.2 & 13.3 & 1.4 & 117 & 8173 & 1.41 \\
\hline C. praecox & - & - & - & 102 & 16218 & 0.6 \\
\hline
\end{tabular}

Table 4

Characteristics of the abaxial leaf epidermis in the four species of the genus Cotoneaster

\begin{tabular}{|c|c|c|c|c|c|c|}
\hline \multirow{3}{*}{ Species } & Length & Width & \multirow{3}{*}{ Shape index } & \multicolumn{2}{|c|}{ Number } & \multirow{2}{*}{ Stomatal index } \\
\hline & \multicolumn{2}{|c|}{ of stomata } & & of stomata & of epidermal cells & \\
\hline & \multicolumn{2}{|c|}{$(\mu \mathrm{m})$} & & \multicolumn{2}{|c|}{$\left(\right.$ per $\left.1 \mathrm{~mm}^{2}\right)$} & $(\%)$ \\
\hline C. divaricatus & 36.6 & 25.0 & 1.5 & 202 & 1037 & 16.3 \\
\hline C. horizontalis & 31.9 & 19.2 & 1.7 & 222 & 1913 & 10.4 \\
\hline C. lucidus & 34.6 & 24.7 & 1.4 & 167 & 1233 & 11.9 \\
\hline C. praecox & 31.5 & 24.5 & 1.3 & 399 & 3156 & 11.2 \\
\hline
\end{tabular}

Among three of the species analysed, $C$. horizontalis flowers produced the largest $(23 / 18 \mu \mathrm{m})$ stomata in the nectary epidermis, while $C$. divaricatus was characterized with the smallest stomata $(18 / 12 \mu \mathrm{m})$ (Table 3$)$. Since the flowers of $C$. praecox are located in depressions, their stomatal size was not checked. The stomata were located at the same level as other nectary epidermal cells (C.divaricatus, $C$. horizontalis, $C$. lucidus) or in depressions $(C$. divaricatus, $C$. horizontalis, $C$. praecox). The stomata were classified as anomocytic. Both open and closed stomatal openings were found during nectar secretion in the nectaries of $C$. horizontalis and C. divaricatus. In the other two species, the stomata were open (Table 2; Figs 2C-E; 3B-E; 4C-E; 5B-D).

The number of stomata per $1 \mathrm{~mm}^{2}$ of nectary epidermis in the taxa under study ranged from 98 to 205. The nectaries are arranged as follows according to the increasing stomatal density: $C$. horizontalis (98), C. praecox (102), C. lucidus (117), and C. divaricatus (205) (Table 3). Stomatal cells are surrounded by 5-7 
epidermal cells in the flowers of $C$. divaricatus, $C . l u$ cidus, and C. praecox, and 8-9 cells in $C$. horizontalis. The distance between adjacent stomata was the smallest in $C$. divaricatus and ranged from 2 to 8 epidermal cells, whereas the distance between stomata and other epidermal cells was $3-15$ cells in the other three taxa (Tab. 2).
The outer cell walls in the nectary epidermis were convex and slightly undulated. The cuticular ornamentation in these cells was diverse. Very distinct longitudinally arranged striae were visible on the stomatal cell surface in the $C$. divaricatus flowers (Fig. 2D, E); the cuticle in the other three species exhibited weaker striation (Figs 3C-E; 4D; 5D).
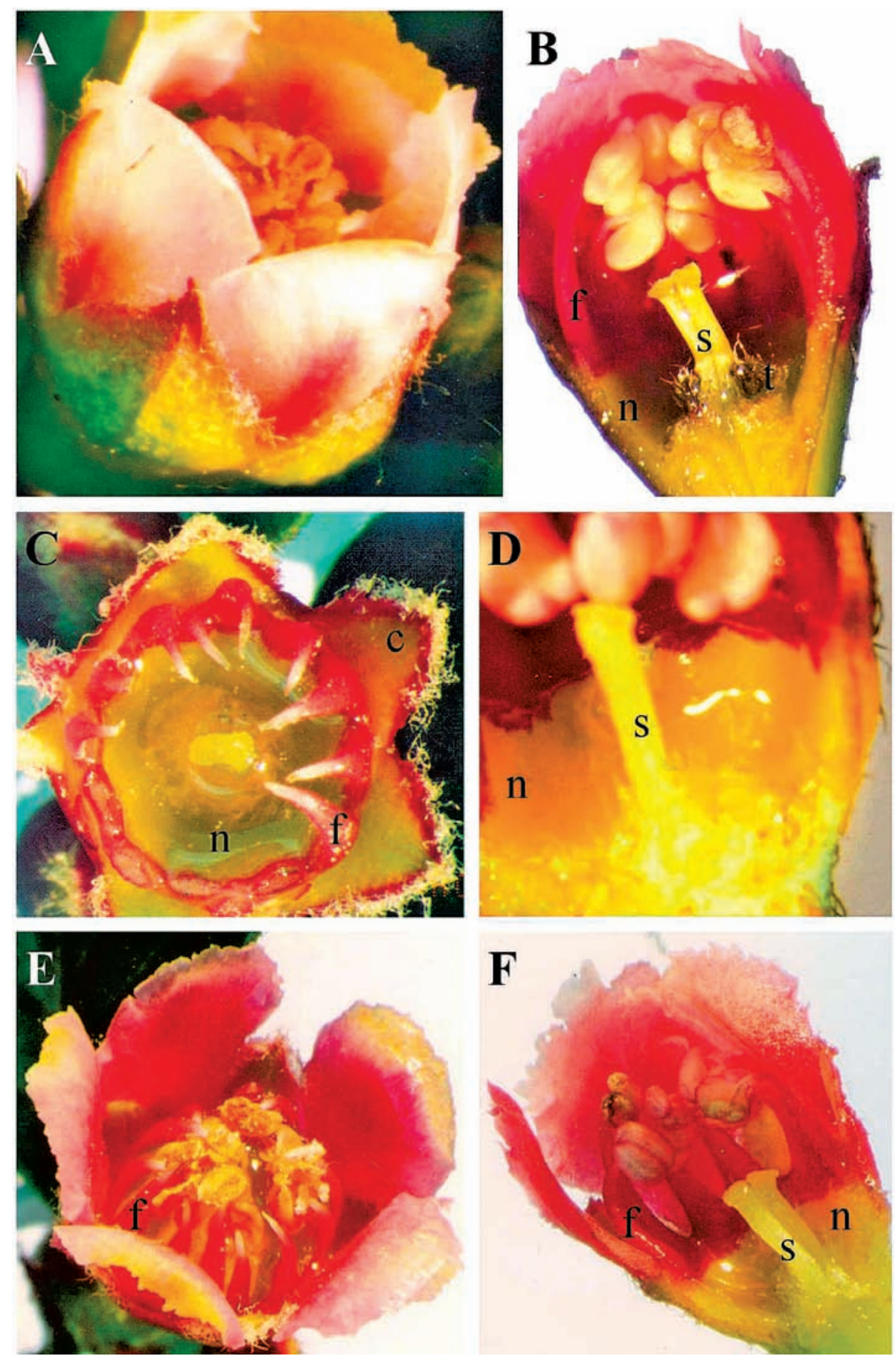

Fig. 1. Flowers of the Cotoneaster species studied and their fragments indicating the location of the nectary (n): A-C. lucidus (x20), B-C. divaricatus (x15); C, D-C. horizontalis (C x14; D x27); E - F - C. praecox (E, F x12); c - calyx, f - filament, s - style, $\mathrm{t}$ - trichomes. 

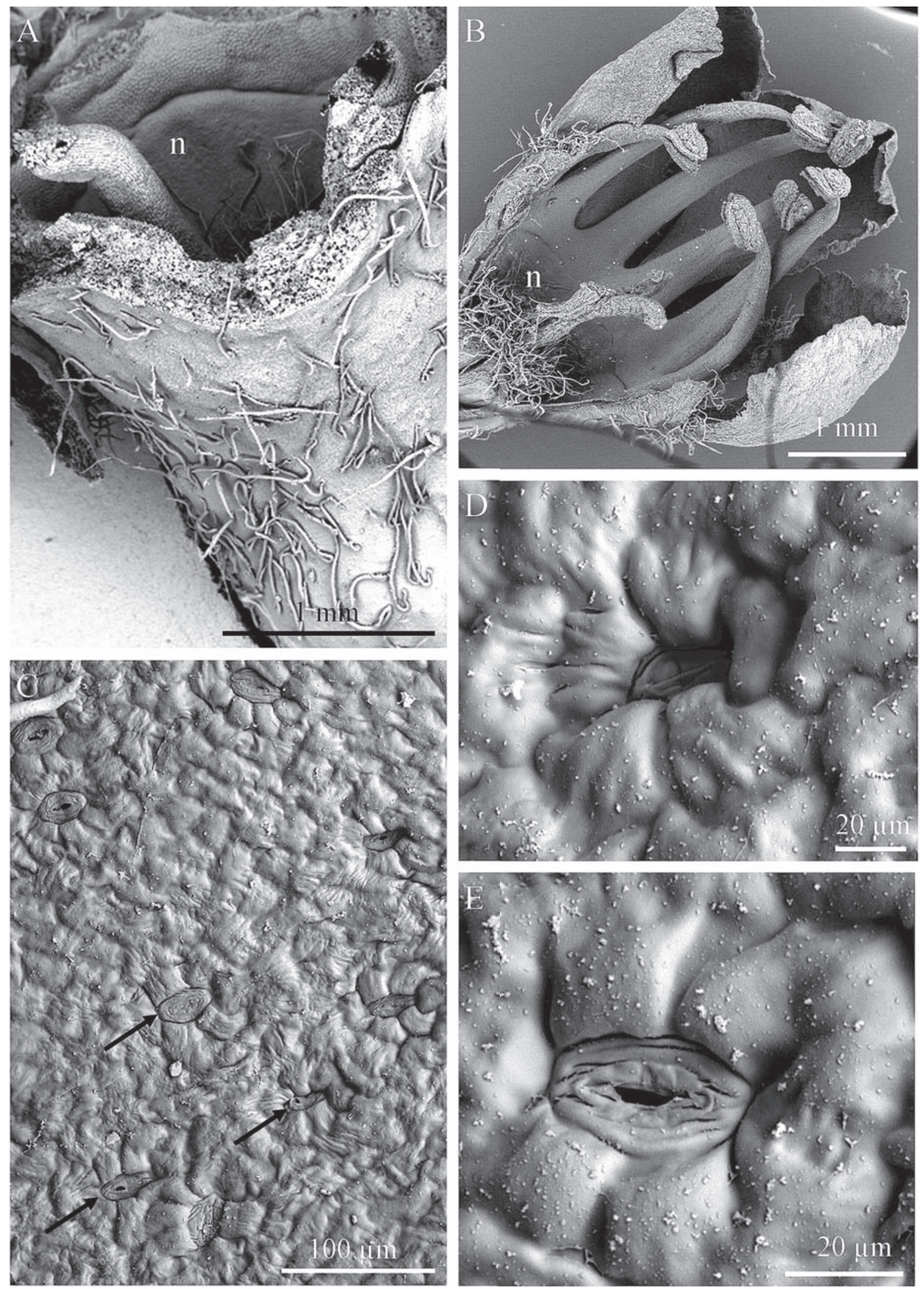

Fig. 2. Fragments of flowers and the nectary surface in Cotoneaster divaricatus: A, B - fragments of flowers with a partially uncovered nectary (n); C - nectary surface with numerous stomata (arrows); D, E - stomata in small depressions surrounded by epidermal cells with different levels of cuticle ornamentation. 

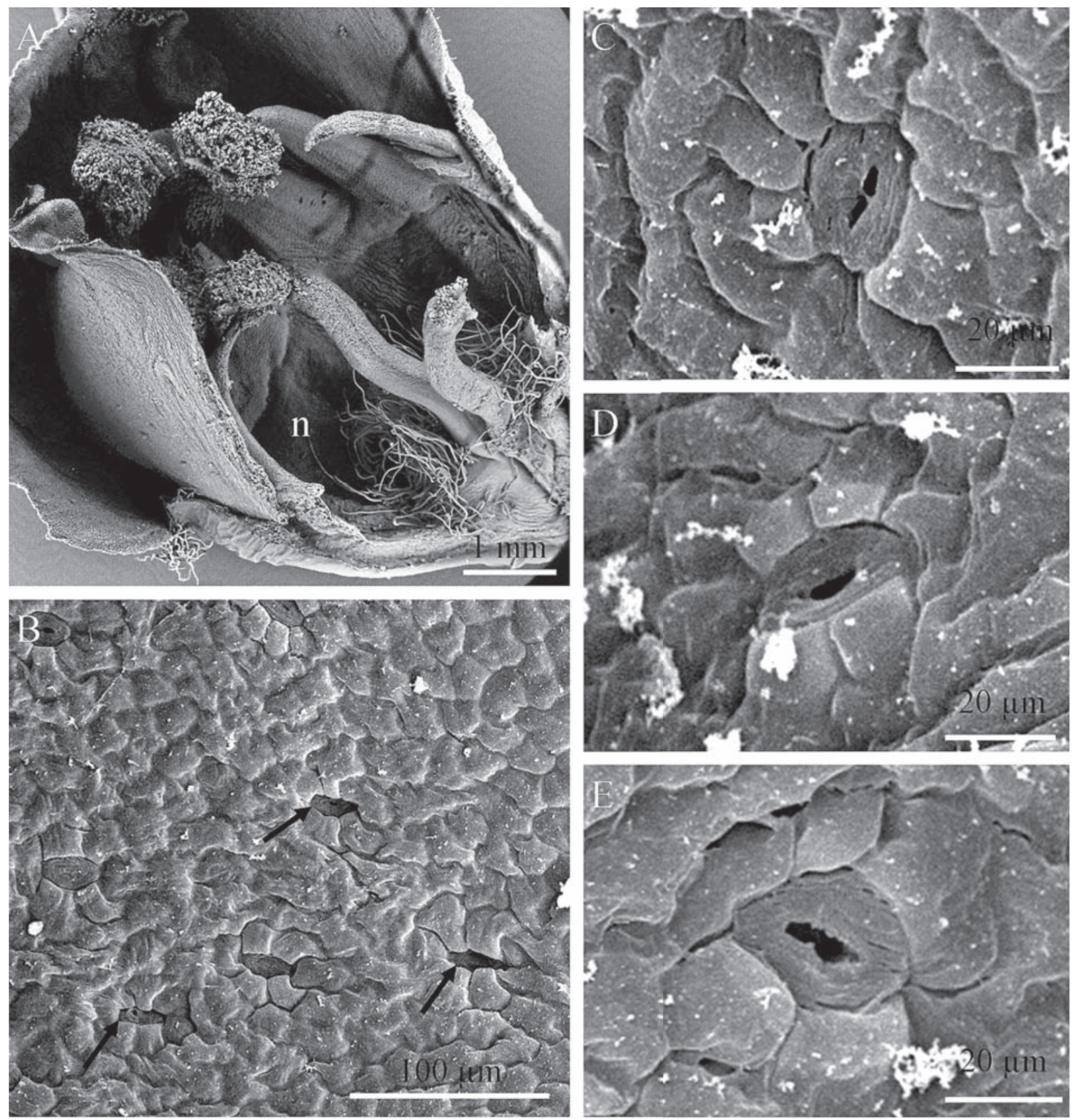

Fig. 3. Fragment of the flower and the nectary surface in Cotoneaster horizontalis: A - longitudinal section of the flower with a visible nectary (n); B - the nectary surface with stomata (arrows); C, D, E- stomata partly hidden by surrounding epidermal cells.

The cuticle on the surface of the cells adjacent to the stomata was smooth or striated, with the striae converging near the stoma. A smooth, undulate or striated cuticle was visible on the surface of other epidermal cells. Cuticular wax, which either had a granular structure or was composed of larger irregular forms, was present on the cuticle surface (Table 2; Figs 2C-E; 3B-E; 4C-E; 5C-D).

The stomata on the abaxial leaf surface in the Cotoneaster species investigated were much larger than those on the nectary surface. In three species, their number per unit area on the leaf surface was 1.5-4 times higher than on the nectary surface. $C$. divaricatus was an exception, as the stomatal densities on the leaf and nectary epidermis were similar, 202 and 205 per $\mathrm{mm}^{2}$, respectively. The stomatal indices calculated for the nectary were markedly lower than for the leaves of the species examined. The shape indices for stomata in the nectary epidermis and leaves were identical only in C. lucidus. The indices for C. divaricatus and $C$. horizontalis taxa differed considerably (Tables 3,4$)$. 

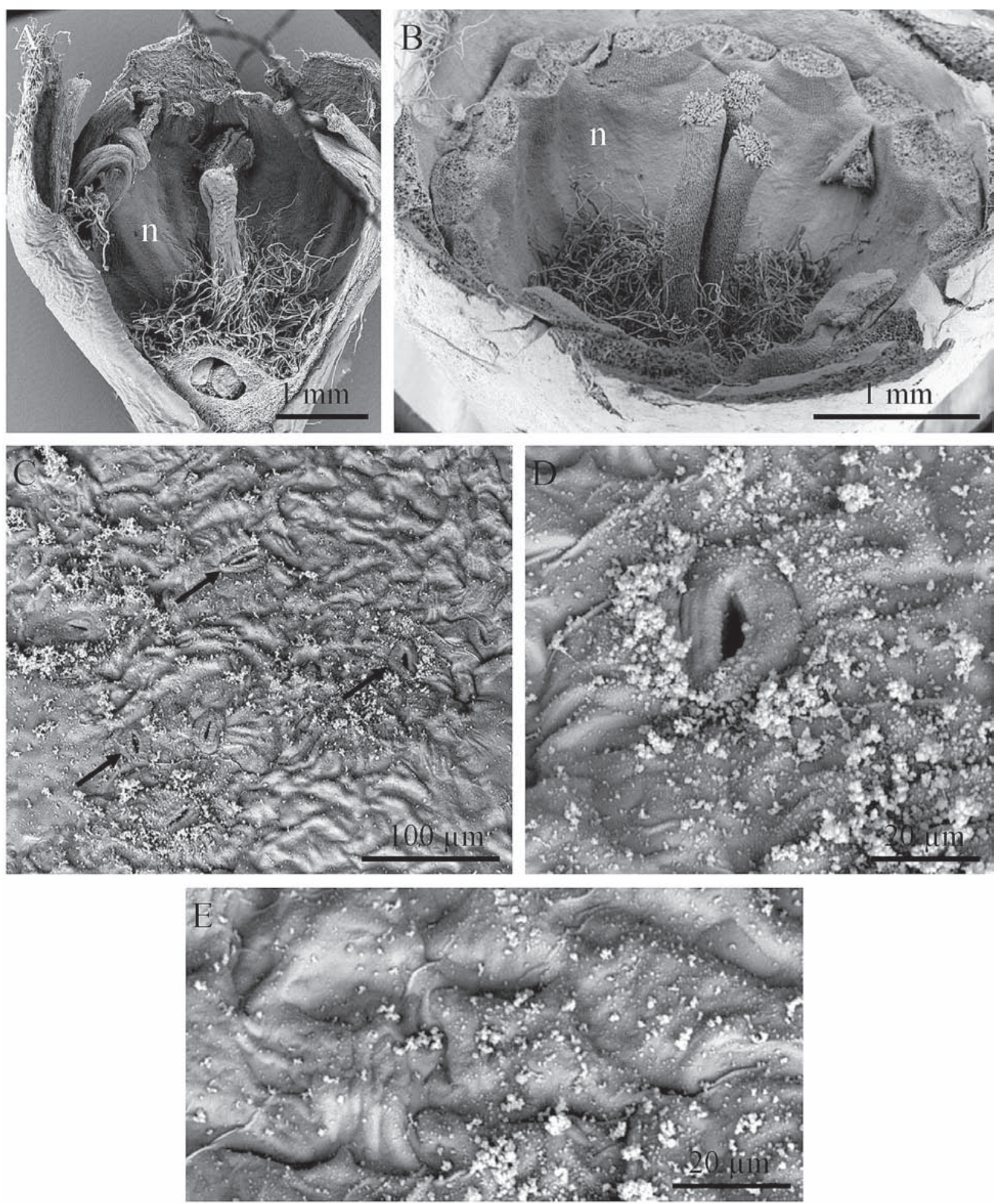

Fig. 4. Fragments of flowers and the nectary surface in Cotoneaster lucidus: A - longitudinal section of the flower with a distinct nectary (n); B - the base of the flower after removal of the perianth and stamens with a distinct nectary (n); C, D, E- fragments of the nectary surface with stomata (arrows); distinct undulate epidermal cell walls, cuticular striae and wax deposit. 

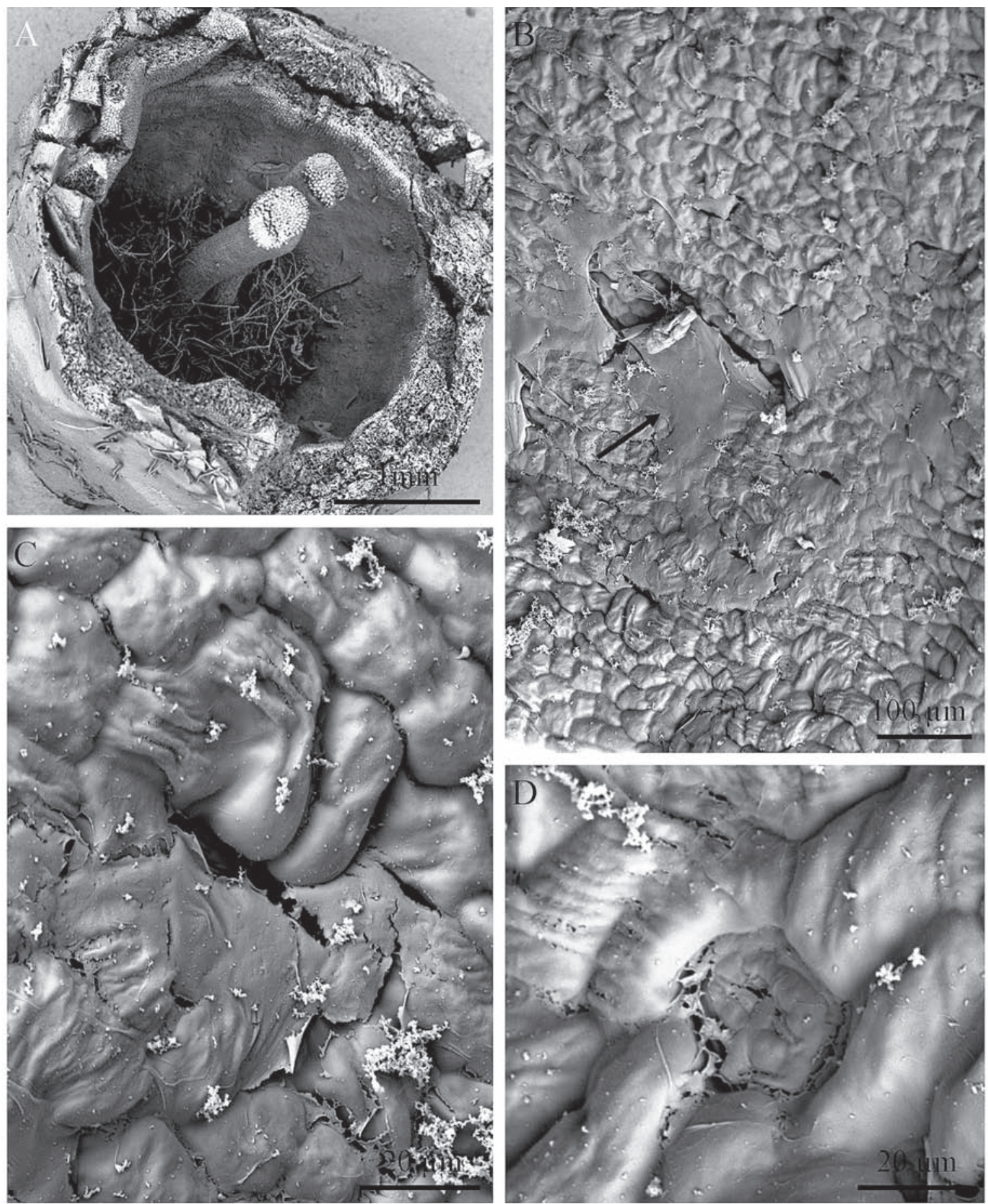

Fig. 5. Fragment of the Cotoneaster praecox flower with a distinct nectary (n) and the nectary surface: A - the base part of the flower with the nectary (n); B - the nectary epidermis surface with nectar residues (arrow); C, D - epidermal cells around the stomata exhibiting distinct an ornamented and ruptured cuticle.

\section{DISCUSSION}

In terms of the nectary size, the Cotoneaster species investigated can be arranged in the following sequence: C. lucidus $>C$. praecox $>C$. horizontalis $>$ C. divaricatus. Previous studies (Wery s zko-Chmielewska and Konarska, 1996;
Weryszko-Chmielewska et al. 2004) suggested the sequence: $C$. praecox $>C$. horizontalis $>$ C. lucidus according to the decreasing thickness of nectariferous tissue. These data demonstrate that the largest nectary in C. lucidus is characterized by the smallest thickness of nectariferous tissue. 
The data presented in this paper show that stomatal density in the nectary epidermis was the highest in $C$. divaricatus, which had the smallest nectary. The literature shows that the greatest amount of nectar was secreted by the flowers of $C$. horizontalis and C. luci$d u s$, markedly lower amounts by $C$. praecox ( $\mathrm{S}$ z k l a nowska, 1978; Weryszko-Chmielewska and Konarska, 1996; Weryszko-Chmiele w s k a et al. 2003, 2004). The highest nectar yield was reported in $C$. horizontalis, while the lowest yield in $C$. praecox, although the stomatal density in their nectary epidermis was similar. Hence, this indicates that the number of stomata does not show a clear relationship with the amount of nectar secreted by the Cotoneaster taxa under study.

The glistening non-glandular trichomes located at the nectary base protect secreted nectar against water loss. Their other possible role is to indicate the nectar location in the flower to pollinators. Evert (2006) reports that trichomes on the leaf surface reduce transpiration by increasing sunlight reflection, which lowers the temperature of the organ by expanding the boundary layer through which water vapour has to diffuse.

In all the Cotoneaster species under study, the outer walls of epidermal cells that formed the nectary surface were undulate; additionally, local cuticle striation of the epidermal cells adjacent to the stomata was reported.

Similar cuticular ornamentation on the nectary surface has been described in flowers of several plant species of the subfamily Pomoideae (Crataegus, $M a$ lus, Pyrus, Sorbus) (Chwil et al. 2006; W e r y s zk o- Chmielew ska and Kon arska, 2006; Nag y - Deri et al. 2007; W e ry s zk o- Ch mi e lew $\mathrm{ska}$ and D mitruk, 2009). The striated structure is conducive to the distribution of nectar over the surface of the nectary epidermis and to storage of the liquid in the hollows between the striae $(\mathrm{Nagy} \mathrm{T}$ óth et al. 2000; N a g y - D e r i et al. 2007). Thicker cuticular striae have been shown to protect better the sugar solution against water loss than thin ones $(\mathrm{Oros} \mathrm{Z}$ - Kovác s et al. 1991). At the same time, such cuticular sculpture, reflecting part of radiation, reduces the heating of the nectariferous tissue ( $\mathrm{He} \mathrm{j} \mathrm{n} \mathrm{o} \mathrm{w} \mathrm{i} \mathrm{c} \mathrm{z,}$ 2002). The cuticle can also participate in nectar secretion (F a h n, 1979). The release of nectar through microchannels in the cuticle, in addition to stomatal secretion, has been found in Prunus pesica by $\mathrm{R} \mathrm{a} \mathrm{d} \mathrm{i} \mathrm{-}$ ce and Galati (2003). According to Kote yeva (2005), the cuticular layer is characterized by a high liquid diffusion rate in the specialized secretory tissues, especially in the nectaries.

The presence of anomocytic stomata found in all the Cotoneaster species studied is in agreement with the data for the family Rosaceae obtained by B rod a (2002) and Evert (2006). The aforementioned stomatal complex lacks subsidiary cells that could be distinguished from other epidermal cells.

At the beginning of nectar secretion, the stomata in a young $C$. horizontalis nectary observed in this study were located below the other epidermal cells; in contrast, a previous paper (W e r y s z k o- C h mi e le w $\mathrm{s} \mathrm{k}$ a et al. 2003) showed that, during intensive nectar secretion, the stomata in this species were located at a higher level. Our observations are consistent with the conclusions of Gaffal et al. (1998) and $\mathrm{Nepi}$ (2007), who claimed that the stomata in active nectaries were slightly raised above the epidermis surface while those in nectaries that had not secreted nectar before were open, but not elevated above the surface.

The stomata were most recessed in Cotoneaster praecox. In the other three species, they were located both in depressions (young stomata) and at the level of epidermal cells (nectar-secreting stomata). In two species, i.e. Cotoneaster divaricatus and $C$. horizontalis, asynchronous functioning of nectarostomata was noted at the time of nectar secretion, as some stomata were open while others were covered by a cuticle.

The stomata in the Cotoneaster species studied differed in their shape. The shape of the stomata in the nectary of $C$. horizontalis was most circular (shape index 1.3), which was more evidenced in our previous work (Weryszko-Chmie lewska et al. 2003). In this study, we observed more or less elongated stomata (shape index 1.4-1.6); some of them had strongly wrinkled epidermal cell walls (C. divaricatus).

The leaf stomata were bigger and had different shapes than those on the nectary surface; the stomata in C. lucidus, which had the same shape, were an exception. The shape index in the nectary and leaf stomata in this species was 1.4. The lower value of the stomatal indices for the nectary epidermis compared to that in the leaf epidermis is probably related to a much smaller size of epidermal cells and lower stomatal density per unit area on the nectary surface. It should be noted that the stomata in the above-mentioned organs perform different functions. In the nectaries, they secrete nectar and often remain open, regardless of the environmental conditions; this suggests the absence of a turgor change, unlike in leaf stomata ( $\mathrm{D}$ a v is and Gunning, 1993; N e pi , 2007).

The leaf stomatal index is a quite constant value for particular species and may indicate the degree of their relatedness. In pharmacognosy, it is an important feature useful for distinguishing medicinal materials (B r o d a , 2002). Atmospheric $\mathrm{CO}_{2}$ has been shown to play an important role in formation of epidermal cell stomata and to affect their number. Therefore, in recent years numerous investigations based on the stomatal 
index have been carried out on the changes in $\mathrm{CO}_{2}$ concentration and climatic changes in the history of vegetation (Roye r, 2001; R undren et al. 2005).

\section{REFERENCES}

Bernardello G., 2007. A systematic survey of floral nectaries. [In]: Nectaries and nectar. S. W. Nicolson, M. Nepi, E. Pacini (eds). Springer, Dordrecht: 19-128.

B roda B ., 2002. Zarys botaniki farmaceutycznej. Państwowe Zakłady Wydawnictw Lekarskich, Warszawa. (in Polish)

Chwil M., Konarska A., Weryszko-Chmielews k a E., 2006. Diversity of the floral nectaries surface of four Crataegus L. species. Acta Agrobot. 59(1): 29-39.

Corbet S.A., Westgarth-Smith A., 1992. Cotoneaster for bumble bees and honey bees. J. Apicult. Res. 31(1): 9-14.

Davis A.R., Gunning B.E.S., 1993. The modified stomata of the floral nectary of Vicia faba L. 3. Physiological aspects, including comparisons with foliar stomata. Bot. Acta 106: 241-253.

Evans R.C., Dickins on T.A.,2005. Flora ontogeny and morphology in Gillenia (Spiraeoideae) and subfamily Maloideae C. Weber (Rosaceae). Int. J. Plants Sci. 166: 427-447.

Evert R.F., 2006. Esau's plant anatomy: meristems, cells, and tissues of the plant body: their structure, function, and development. Third edition. John Willey \& Sons Inc. Hoboken, New Jersey: 214-221.

Fahn A., 1979. Ultrastructure of nectaries in relation nectar secretion. Am. J. Bot. 66: 977-985.

Gaffal K.P., Heimler W., E1-Gammal S., 1998. The floral nectary of Digitalis purpurea L., structure and nectar secretion. Ann. Bot. 81: 251-262.

Hejnowicz Z., 2002. Anatomia i histogeneza roślin naczyniowych: organy wegetatywne. Państwowe Wydawnictwo Naukowe, Warszawa. (in Polish)

Jabłoński B., Kołtowski Z., 1996. Nektarowanie i wydajność miodowa roślin miododajnych w warunkach Polski. / Nectar production and honey yield of melliferous plants under Polish conditions. Pszczeln. Zesz. Nauk. Cz. IX. 40(1): 59-65. (in Polish).

Koteyeva N.K., 2005. A novel structural type of plant cuticle. Dok. Biol. Sci. 403: 283-285.

Mirek Z., Piękoś-Mirkowa H., Zając A., Zają c M., 2002. Flowering plants and pteridophytes of Poland. A checklist. W. Szafer Institute of Botany, Polish Academy of Science, Kraków.

Nagy Tóth E., Bubán T., Hevesi M., OroszKovács Z., Szabó L.G., 2000. Morphological characteristics of the nectary and composition of nectar in flowers of selected apple cultivars. Acta Hort. 538(1): 301-308.

Nagy-Deri H., Orosz-Kovács Z., Farkas A., 2007. Morphological characterization of the floral nec- tary in some apple-shaped and pear-shaped quince cultivars. Acta Bot. Hung. 49(3/4): 359-375.

Nepi M., 2007. Nectary structure and ultrastructure. [In]: Nectaries and nectar. S. Nicolson, M. Nepi, E.Pacini (eds). Springer, Dordrecht: 129-166.

Orosz-Kovács Z., Gulyás S., Kaposvari F., 1991. Nectary surface of plum varieties. Acta Bot. Hung. 36: 211-217.

Radice S., Galati B.G., 2003. Floral nectary ultrastructure of Prunus persica (L.) Batch cv. Forastero (Newcomer), an Argentine peach. Plant Syst. Evol. 238: 23-32.

Royer D.L., 2001. Stomatal density and stomatal index as indicators of paleoatmospheric $\mathrm{CO}_{2}$ concentration. Rev. Palaeobot. Pathol. 114: 1-28.

Rundgren M., Björck S., Hammarlund D., 2005. Last interglacial atmospheric $\mathrm{CO}_{2}$ changes from stomatal index data and their relation to climate variations. Glob. Planet. Change, 49: 47-62.

Rutkowski L., 2006. Klucz do oznaczania roślin naczyniowych Polski niżowej. Państwowe Wydawnictwo Naukowe, Warszawa. (in Polish)

Seneta W., Dolatowski J., 2004. Dendrologia. Polskie Wydawnictwo Naukowe, Warszawa. (in Polish).

S mets E., 1986. Localization and systematic importance of the floral nectaries in the Magnoliatae (Dicotyledons). Bull. Jard. Bot. Nat. Belg. 56: 51-76.

Szk la nowska K., 1978. Nektarowanie i wydajność miodowa niektórych drzew i krzewów w warunkach Polski. / Nectar production and honey yield of some trees and shrubs under Polish conditions. Pszczeln. Zesz. Nauk. 22: 117-128. (in Polish)

Szweykowscy A. J., 2003. Słownik botaniczny. Wiedza Powszechna, Warszawa. (in Polish).

Weryszko-Chmielewska E., Chwil M., Skrzypek H., 2003. Charakterystyka kwiatów i nektarowanie irgi miseczkowatej Cotoneaster hjelmqvistii. I Characteristics of flowers and nectar secretion in $\mathrm{Co}$ toneaster hjelmqvistii. Ann. Univ. Mariae Curie-Skłodowska, sect. EEE, Hortic. 13: 137-142. (in Polish).

Weryszko-Chmielewska E., Chwil M., Konarska A., 2004. Anatomical traits of nectaries and nectar secretion by the flowers of Cotoneaster lucidus Schlecht. and C. nanshan Mottet. J. Apicult. Sci. 48(1): 57-64.

Weryszko-Chmielewska E., Dmitruk M., 2009. Characteristics of blooming, floral nectaries and nectar of Malus sargentii Rehd. Acta Agrobot. 62(1): 17-25.

Weryszko-Chmielewska E., Konarska A., 1996. Anatomia nektarników kwiatowych dziewięciu gatunków z podrodziny Pomoideae (Rosaceae). / Anatomy of floral nectaries in nine species of the subfamily Pomoideae (Rosaceae). Acta Agrobot. 49(1-2): 95-105. (in Polish).

Weryszko-Chmielewska E., Konarska A., 2006. Mikromorfologia powierzchni nektarnika jarzębu szwedzkiego (Sorbus intermedia Pers.) w różnych 
fazach kwitnienia. / Micromorphology of Sorbus intermedia Pers. nectary surface in different phases of blooming Acta Agrobot. 59(1): 49-59. (in Polish).

\section{Porównanie cech epidermy i wielkości nektarnika kwiatowego czterech gatunków z rodzaju Cotoneaster Med.}

\section{Streszczenie}

Badano 4 gatunki z rodzaju Cotoneaster: $C$. divaricatus, $C$. horizontalis, C. lucidus, $C$. praecox, które należą do często sadzonych krzewów ozdobnych. W warunkach Polski rośliny te kwitną w maju i czerw$\mathrm{cu}$, są dobrym źródłem wiosennego pożytku nektarowego dla owadów. Nektarniki kwiatowe wymienionych gatunków badano przy zastosowaniu mikroskopii stereoskopowej, świetlnej i skaningowej elektronowej określając ich wielkość i mikrostrukturę epidermy. Tkanka nektarnikowa badanych roślin wyściela górną powierzchnię hypanthium. Nektarniki czterech gatunków różnią się wielkością. Wydzielanie nektaru na powierzchnię epidermy odbywa się za pośrednictwem anomocytycznych aparatów szparkowych o lekko wydłużonym lub kolistym kształcie. Największe aparaty szparkowe w epidermie nektarnika wykształcały kwiaty $C$. horizontalis, a najdrobniejsze $C$. divaricatus. Ich wielkość i położenie w stosunku do innych komórek epidermy były zróżnicowane w zależności od taksonu. Największe zagęszczenie szparek w epidermie nektarnika stwierdzono u C. divaricatus $\left(205 \mathrm{w} \mathrm{mm}^{2}\right)$, a najmniejsze w kwiatach $C$. horizontalis $\left(98 \mathrm{w} \mathrm{mm}^{2}\right)$. Ornamentacja kutykularna na powierzchni epidermy nektarników była zróżnicowana. Indeksy szparkowe obliczone dla epidermy nektarnika były znacznie mniejsze niż dla liści odpowiednich gatunków. 
